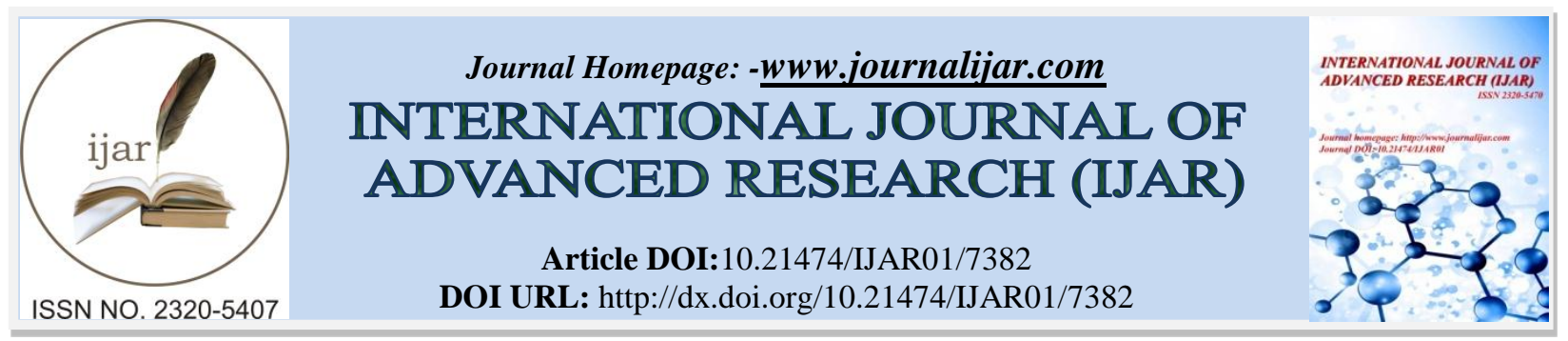

RESEARCH ARTICLE

\title{
THE ROLE OF BUSINESS PARTNERSHIP AND SUPPLY CHAINS MANAGEMENT OF SMALL- MEDIUM ENTERPRISES IN SURABAYA.
}

Lena Ellitan and Dominicus Wahyu Pradana.

Faculty of Business, Widya Mandala Catholic University Surabaya, Indonesia.

\section{Manuscript Info}

Manuscript History

Received: 10 May 2018

Final Accepted: 12 June 2018

Published: July 2018

Keywords:-

SCM, business partnership, competitive advantage and SMEs.

\begin{abstract}
SCM will face increasingly serious challenges, as the complexity of consumer demand and intercompany relationships in the value chain are increasing. Research on supply chain analysis and design in enhancing competitive advantage is important for companies of both large and medium scale. Supply chain management essentially covers the scope of work and responsibility. All activities related to the flow of materials, information, and money along the supply chain are activities within the scope of supply chain management. This study investigate the role of business partnership and SCM to increase SMEs competitive advantage. This study found that the focus of the evaluation of potential business partners is to get an integrative partnership. Integrative relationships add value to market supply. Companies involved in a business partnership should be able to create value or at least provide added value to market supply. The creation of this value depends on the firm's core capabilities that tend to be limited because the technology required to produce the product requires a high cost and complex business environment. To increase the company's ability to create value, the company must be able to get potential business partners and can manage the partnerships formed so that each party can enjoy the benefits generated from the cooperation.
\end{abstract}

Copy Right, IJAR, 2018,. All rights reserved.

\section{Introduction:-}

\section{Background of the Study:-}

Conditions of intense business competition require companies to implement strategic policies, not least Small and Medium Enterprises (SMEs). SMEs have an important role in the Indonesian economy. Due to this SMEs, unemployment due to the unabsorbed labor force in the workforce is reduced. SME sector has been promoted and made as the main agenda of Indonesia's economic development. One of the efforts that SMEs can survive in the long run is the provision of the right product for consumers, at the right time, and in economic cost. The availability of the product and the economical selling price can only occur if there is good coordination between the company and the parties in the supply chain (Permana, et al 2017). Coordination of the parties in the supply chain involves not only supply coordination but also market information useful for enterprise planning.

Lack of product inventory will result in loss of sales, while certain advantages will result in accumulation of products and increased inventory maintenance costs. In addition, coordination with sales networks as one of the supply chain is important (Sondakh, et al., 2018). Thus the role of suppliers, transportation companies, and

Corresponding Author:-Lena Ellitan.

Address:-Faculty of Business, Widya Mandala Catholic University Surabava, Indonesia. 
distributorship network is needed for the survival of SMEs. Awareness of cheap, fast and quality products that develop to the new concepts in Supply Chain Management. Supervision Chain Management is a concept or mechanism to improve the total productivity of a company in the supply chain through the optimization of time, location and quantity flow of materials. Companies including SMEs in the application of SCM are required to satisfy customers, develop products in a timely manner, spend low cost in the field of inventory and product delivery, manage the industry carefully and flexibly. Nowadays consumers are increasingly crisp and demanding products with fast delivery. SCM becomes one of the best solutions to improve productivity through effectiveness and efficiency between different companies.

Kurniawan (2018) argues that there are many complaints that often arise in discussions about SCM, among others: a. consumer dissatisfaction and the occurrence of lost sales with respect to shortage of inventory b. supplier problems resulting in the late introduction of new products to the market c. excess inventory and product expiration d. major suppliers are often out of business. In the future, SCM will face increasingly serious challenges, as the complexity of consumer demand and intercompany relationships in the value chain are increasing. Research on supply chain analysis and design in enhancing competitive advantage is important for companies of both large and medium scale.

\section{Literature Review:-}

\section{Supply Chain Management:-}

Supply chain management is an alternative strategy that provides solutions in the face of environmental uncertainty to achieve competitive advantage through reduced operating costs and improved customer service and customer satisfaction. Supply chain management offers a mechanism that governs business processes, increases productivity, and reduces company operating costs.

Lee \& Whang (2000) defines supply chain management as business process integration from end users through suppliers that deliver products, services, information, and even value enhancements to consumers and employees. Through the supply chain, companies can build cooperation through the creation of a coordinated network in the provision of goods and services for consumers efficiently (D'Amours et al., 1999). One of the most important things in supply chain management is the sharing of information, therefore in the material flow, cash flow, and information flow are all elements of the supply chain that need to be integrated (Chen et al., 2004).

The principle of supply chain management is basically synchronization and coordination of activities related to material / product flow. A simple supply chain has components called a channel consisting of suppliers, manufacturers, distribution centers, wholesalers, and retailers who all work to meet end customers. A supply chain may involve a number of manufacturing industries in an upstream to downstream chain. A supply chain is not always a straight chain (Anatan \& Ellitan, 2009).

In reality, a manufacturing industry can have hundreds or even thousands of suppliers, and products produced by an industry are distributed to multiple centers serving hundreds or even thousands of wholesalers, retailers, merchants, and consumers. And each channel in a supply chain has mutually supportive activities including product design, demand forecasting, material procurement, production, inventory control, distribution, transportation, deviation or warehousing, customer service support, and payment processing. Management of supply chain management requires the intervention of the relevant parties (Muljani \& Ellitan, 2017). Supply chain management applications basically have three main objectives: cost reduction, capital reduction, and service improvement. Cost reductions can be achieved by minimizing logistics costs, for example by choosing a transport tool or model, warehousing, service standards that minimize costs. To achieve the required capital decline in business activity, firms must be able to minimize the level of investment in logistics. While the improvement of service is very important to be done proactively because the service or logistics services that the company greatly affects the income and profitability of the company. Supply chain management essentially covers the scope of work and responsibility. All activities related to the flow of materials, information, and money along the supply chain are activities within the scope of supply chain management.

\section{Coordinated Business Partnership:-}

The conditions of business competition in today's global market are highly volatile and unpredictable, and characterized by changes in consumer needs and wants, and rapid technological development. World-class global companies operating in global markets must be capable of world-class performance. In this condition, having the 
right product at the right place and time will allow the company to win the existing competition. But the resources and competencies required are often not owned by an individual company, so cooperation or collaboration with other companies in a business network is necessary to support the process of product innovation and achieve business efficiency and effectiveness (Anatan \& Ellitan, 2009). As a result, creating customer value in a business network becomes an important issue in the development of inter-company collaboration to improve the competitiveness of enterprises.

In the face of increasingly unpredictable competitive conditions, proper business planning is required through the business transformation process from the simulation model of business decision support support systems into decision analysis capabilities related to revenue and profit sharing (Ellitan \& Anatan, 2007). Companies are facing stronger pressures to improve operational efficiency in order to achieve improved competitiveness and overall business performance. The pressures that the company faces not only from the side of unanticipated consumer demand and the rapid advancement of communication technology and information technology but also because of increased competition between one business network with other business networks and the increasing introduction of competing products that result in the shortening product life cycle (Browne et al., 1995).

The trend of economic globalization has shifted the paradigm in business competition between individually companies into business competition between business networking. This condition lead to the need for corporate transformation in service and customer value creation through a manufacturing network, so that the majority of companies' manufacturing processes need to be oriented to create the value of business networks (Rudberg \& Olhager, 2003). The process of creating business value networks requires the support of increased efficiency and effectiveness of internal business operations such as purchasing, warehousing, material management and distribution (Muljani \& Ellitan, 2017). Therefore, effective cooperation between companies, both competitors and suppliers in a business network needs to be established based on coordination so that the company can produce high quality products according to demand and market needs in a timely manner in response to existing business challenges.

The concept of collaboration in business network becomes an interesting issue in an increasingly competitive competitive environment (Clark \& Hammond, 1997). This concept emphasizes the integration of the flow of information and materials through business networks to support the innovation process of the company which is an important thing to achieve increased capability of the company in meeting consumers needs and desires (Lee \& Whang, 2000).

The company's flexibility and capability to respond to consumer demand for more varied products can be done using customization production systems and by applying product design to achieve broader market segmentation. The development of technology and the growth of business environment, as well as the shorter product life cycle encourage companies to produce different products with other products more quickly. Inter-company collaboration in business networks becomes an important issue for companies because this integration enables companies to gain competitive advantage through superior customer value creation and improve their business processes.

Improving competitiveness for all partners is a key objective of establishing business partnerships. Partnerships are a coordinating mechanism for suppliers and companies in creating value-added within business networks. Partnership is a type of relationship where responsibilities and potential benefits are distinguished from one form of coordination related to seller and buyer relations in general and specific levels of investment in particular (Rudberg \& Olhager, 2003). The two main reasons for establishing intercompany relationships in a coordinated business network are (1) to deal with differences or inconsistencies between products in different business networks that affect consumers and to complement competing systems with each other. Increasing competition between standards and implementation of success determines the success of the partnership, 2) to improve supplier efficiency in developing effective strategies so as not to negatively impact product quality and reliability. Value creation in a business network can achieve success if coordination between all parties involved in the partnership. The idea of partnerships in business relationships between companies and the process of value creation in business networks becomes an important issue because the overall potential relationship in the business network can be found trust partnership so that transaction costs are relatively low because it takes a low control as well.

The focus of the evaluation of potential business partners is to get an integrative partnership. Integrative relationships add value to market supply. Companies involved in a business partnership should be able to create value or at least provide added value to market supply. The creation of this value depends on the firm's core 
capabilities that tend to be limited because the technology required to produce the product requires a high cost and complex business environment. To increase the company's ability to create value, the company must be able to get potential business partners and can manage the partnerships formed so that each party can enjoy the benefits generated from the cooperation.

\section{Findings and Discussion:- Participants' Profile:-}

This research was conducted by using Focus Group Discussion in the first phase followed by 20 participants in the FGD and subsequently performed second stage interviews to 6 owners or SMEs in the second stage representing 6 categories of SMEs. Twenty have participated in the Focus Group Discussion, according to the criteria used for this study. Participating companies are selected in the course of business, in the case of business ownership, length of operations, assets owned, and general performance achieved over the past 3 years. These companies are engaged in different businesses according to 6 categories. All of them are small, and medium enterprises that have been in their own business for more than three years, and only 3 relatively new companies (operating less than a year).

\section{SMEs Experience and Lesson Learned Related to Business Management and Supply Chain:-}

Most SMEs are still trying to compete in terms of price. Very few people think of creating unique products, creating messages and marketing materials, asking customers to provide opinions about a given product or service. Nevertheless, fifty percent of business actors have done marketing planning. SME product development is slow due to access to capital and slow innovation. SMEs are also limited in conducting market research. Most SMEs are managed by families and have no cooperation with outside entities. It is not uncommon for SMEs to suffer business losses. However, for business actors who sell goods that can not rotten does not cause significant losses. Here is a sharing of one of the fuel suppliers in hotels, restaurants and big shops. These business actors only feel the business crowded or quiet. To avoid loneliness of business in the long term, entrepreneurs strive to get customers that can be trusted. Another strategy is to get established customer organizations not individual customers. Never take too much profit, always trying to create barganing power with suppliers and customers, and providing faster service to customers is what keeps this business away from a loss risk.

Another experience shared by the florist in the Kayun area, to overcome the possible loss of business is to sell raw material in the sense of interest that has not been stringed. Efforts to diversify the flower arrangements are also done. Employers also sell at a cheaper or competitive price than existing competitors. Maintaining customer loyalty is especially important in maintaining relationships with customers of major agencies. However, it takes patience in terms of billing and payment time from the customer. Billing customers from outside the city is felt more difficult, so from this experience business actors advise better customers make payments first.

For the food business is not uncommon to face the risk of loss, especially in the early days of business. The main thing to do is to find out consumer responses about the results of food products sold, consumer tastes, taste and purchasing power. In addition, the business location factor also needs to be considered. Doing business in the field of food needs to be careful to read the market when busy and quiet, so when quiet do not do too much production. Not infrequently diversified food business so that not only sell one type of food alone. Some businesses start their business driven by the workplace layoffs. They also do not love to spend money, savings or debts from cooperatives or banks. Mental factors to rise is necessary in the deterioration of business. One of the informants working in the field of auto parts and building tools is looking for competitive suppliers, so they can provide cheaper prices to customers with the same quality of goods on the market.

For the clothing retailer, rarely faces the risk of loss. Usually they take goods from factories and have capital trust they pay when marketed products are sold. In this business there is only crowded or lonely. The Eid or Christmas season is a very lucrative moment for this business. For retails that sell to the individual usually provide payment time with installments one-2 months. Retailers acting as wholesalers should ask customers to pay in advance. In addition, the ability to lobby and attract customers and maintain good relationships with suppliers and customers is needed in this business.

Sharing continues with solutions in business. Most entrepreneurs are not afraid of competition. As proposed by one of the informants engaged in the business of ornamental plants in the area Bratang. He applied the strategy by providing competitive prices and good quality of crops. Do not use the services of a realtor making this business can sell with competitive prices, because in this business is usually a realtor sells at very high prices. In addition it is 
necessary to maintain loyalty and build trust with suppliers and customers. Another problem faced is rogue employees who do not work optimally when not supervised. The aspect of employee honesty also determines the success of the business.

One entrepreneur engaged in the field of apparel wholesale business also states not afraid of rival business because he sells at cheaper price with good quality. This can be done because of the suppliers who provide competitive prices and more trust given by the supplier. Creating a network on a continuous basis determines the development of this business, therefore, usually the development of networks through colleagues, church friends, friends are very necessary. Trust and honesty need to be upheld in doing business so it is easier for us to find a distributor.

A businessman who owns a computer buying and selling business in THR Mall also share experiences in this opportunity. The point at all is not afraid to face competition during the competition is a healthy competition. Also advised do not be afraid to owe, debt is used as capital not for consumption. Building cooperation with banks and cooperatives is essential in this endeavor. The payback system in the business of buying and selling computers has been providing good results. Likewise for business boarding house.

Various strategies to get customers or new customers to order are also done by SMEs actors. For entrepreneurs who move the food industry attract new customers by providing the best products according to taste, always think positive and serve customers wholeheartedly, and have mental steel. In addition it must continually offer to old customers and communicate well with customers. Building a network is needed by business actors. Offering low prices and providing long term payback is a good strategy for SMEs too. Common problems facing SMEs are limited funds, business location, no guarantees for bankers, business permits and cooperative education.

\section{Importance of Building Partnerships in Boosting Supply Chain Management Performance:-}

Regional development is largely dependent on partnerships between government, businesses and non-governmental organizations. This partnership facilitates coordination and cooperation. Local partners from private sector can help to exploit local opportunities in developing policies and strategies that meet local needs. A key element of this partnership is the mechanism for different managers and coordinating different resources and efforts of different actors. Planning and implementation is implemented with each ability and strength. During this process it is important to note, that is to form a network of cooperation and develop mutual trust.

Due to the limitations of institutionalization, partnerships for regional development are often less stable. Therefore local governments should take the lead in establishing a stable and formal mechanism to provide partnerships as an institutional basis and the ability to design and implement development plans. The concept of publicity for regional development is closely related to corporate social responsibility. In line with the CSR philosophy, the company wants to dedicate itself to building local partnerships, strengthening local capacity, protecting the environment and contributing funds for regional development.

\section{Conclusions and Suggestions:-}

One of the keys to corporate success in business competition is to own and retain a competitive advantage lying in the company's ability to differentiate itself from competitors and the ability to perform production at a lower cost. This can be achieved through supply chain management and business building partnerships and business networks. (Anatan and Ellitan, 2009). Competitive advantage can be achieved when the company achieves high productivity that is, if it performs production with higher production volume so that the cost per unit is smaller because the fixed cost is smaller if divided by the larger production volume, while the variable cost is fixed, so the total cost is smaller. Some activities that can support the achievement of high productivity include reducing the inventory of the planned capacity. inventory control functions, manufacturing functions, and distribution functions, all of which can be accomplished through collaboration with business partners in a business network.

The trend of globalization has shifted the paradigm in business competition between individual companies into business competition between business networks. This condition requires the company to no longer focus on stand alone-competition but rather on cooperative competition in ecosystem partnership. Companies must change the way companies serve and deliver customer value through manufacturing networks (Ellitan and Anatan, 2008). The concept of business networking offers solutions in the face of business environments uncertainty through reducing operating costs and improving customer service and customer satisfaction through value creation in business networks. The value creation uses three main concepts or core concepts, namely core capability, superior customer 
value (Barner, 1991). To achieve a successful business partnership of several points or approaches are addressed (Anatan \& Ellitan, 2009): 1) radical thinking, 2) enhancing competitive ability together, 3) integrating corporate culture or even different national cultures, 4) development of R \& D facilities or research networks.

\section{Reference:-}

1. Alan S., and Andreas, D. 2007 "Developing a decision-making framework for implementing purchasing synergy: a case study“. International Journal of Physical Distribution \& Logistics Management. Vol. 37. No.1, p. 64-89.

2. Anatan, L. \& Ellitan, L. 2009. Supply Chain Management: Teori dan Aplikasi, Alfabeta Bandung (ISBN:978979-8433-99-3).

3. Barney, J. B. 1999. Firm Resources and Sustained Competitive Advantage. Journal of Management, Vol 17, p.99-120.

4. Browne, J., Sackett, J., Wortmann, J., 1995. Future manufacturing systems-towards the extended enterprise. Computers in Industry 25, 235-254.

5. Clark, T.H., Hammond, J.H., 1997. Reengineering channel reordering process to improve total supply chain performance. Production and Operation Management, 6 (3), 248

6. Ellitan, L. \& Anatan, L. 2007. Manajemen Operasi dalam Era Baru Manufaktur, Alfabeta, Bandung (ISBN: 978-979-8433-35-1).

7. Ellitan, L. \& Anatan, L. 2008. Manajemen Operasi: Konsep dan Aplikasi, Refika Aditama, Bandung (ISBN: 979-1073-98-8).

8. Ellitan, L. 2017. The Role of Partnership on Resource-Performance Relationships of Indonesia SMEs, International Review of Management and Business Research, Vol 6 Issue 3, pp. 1116-1125.

9. Kurniawan, R., Cristiananta, B., Ellitan., L. 2018. Evaluation of Corporate Strategy and Dynamic Capability to Business Performance, International Journal of Scientific Research and Management, Volume 06 Issue 03 March 2018, pp. 199-2016

10. Lee,H.L., Whang, D., 2000. Information sharing in a supply chain. International Journal of Manufacturing Technology and Management, 1 (1), 79-93.

11. Muljani, N. and Ellitan,L. 2017. The Effect Of Information Sharing And Quality Of Information On The Performance Of Supply Chain: The Case Of East Java Manufacturing SMEs., International Journal of Advanced Research, Vol 5 Issue 7, pp. 593-599.

12. Pelhalm, A. M. 2000. "Market Orientation and Other Potential Influence on Performance in Small and Medium-Sized Manufacturing Firms.” Journal of Small Business Management, Vol. 38(1), p.48-67.

13. Permana, A., Laksmana, A., Ellitan, L. 2017. The Effect of Environmental Dynamism, Dynamic Managerial Capabilities, and Deliberate Organizational Learning on the SMEs Performance with Dynamic Capabilites ad Moderator Variable: A Case Study on Small SMEs in Surabaya, International Journal of Advances. Research, 5(7), 540-551.

14. Rudberg, M., Olhager, J., 2003. Manufacturing network and supply chain: an operation strategy perspective. Omega (31), 29-39.

15. Sondakh, O, Christiananta, B. Ellitan, L. 2018. Analyzing the Industrial Forces of Food Industry SMEs in Surabaya-Indonesia, Scholars Journal of Economics, Business and Management (SJEBM), Vol 5(3): 158-166. 